\title{
ANATOMICAL CHANGES OF KEKABU WOOD (Bombax ceiba L.) DUE TO MECHANICAL DENSIFICATION
}

\author{
Krisdianto and Jamal Balfas ${ }^{1}$
}

\begin{abstract}
Kekabu wood (Bombax ceiba L.), which is locally known as kapok or randu has long been planted as crops troughout the country, as fiber producer aimed for stuffing pillow. This species is considered as a giant tree which could produce a large quantity of timber. Unfortunately, the timber is too soft, having low density and several physical defects during drying, limiting its uses in conventional wood processing. Any treatment which could significantly increase its structural density may be useful for diversifying the uses of this timber. This study examined some anatomical changes that may exist during mechanical densification. Wood samples measuring $40 \mathrm{~mm}$ thick, $40 \mathrm{~mm}$ wide and $500 \mathrm{~mm}$ long were steamed at $126^{\circ} \mathrm{C}$ for 30 minutes prior to pressing of $23.75 \mathrm{~kg} / \mathrm{cm}^{2}$. Anatomical measures were undertaken using light microscope and scanning electron microscope on both treated and untreated samples. Results showed that the treatment significantly reduced void volume and ray distance of approximately a half the initial wood structure, followed by an increased in wood density of more than $50 \%$.
\end{abstract}

Keywords: kekabu, lightweight, density, compression, anatomy

\section{I.INTRODUCTION}

Kekabu is a trade name of Bombax ceiba $\mathrm{L}$. wood, which is popularly known as kapok or randu wood. It is formerly named Gossampinus malabarica DC. Merr. and belongs to fạmily Bombacaceae. In some area kekabu wood is mixed in consignments that are mainly comprising wood of Durio spp. and traded as 'durian wood'. Kekabu's heartwood is not clearly demarcated with its white yellowish sapwood. Wood texture is smooth and even, so that clean yellowish kekabu wood appearance is potentially developed as luxury timber. However, kekabu is a lightweight wood. The average density is about $0.30 \mathrm{~g} / \mathrm{cm}^{3}$ that ranges from 0.12 to $0.51 \mathrm{~g} / \mathrm{cm}^{3}$ (Oey, 1990). Due to its low density, kekabu wood has not been utilised as furniture as well as construction materials, making it traded cheaply in local market (Ba and Nghia Tin, 1998).

Density is the weight of substances per unit of volume. In this case, wood density is the weight of wood cell components that build wood structure per unit of volume. It has a positive relation to the thickness of the wood cell wall and is influenced by variation in the relative proportions of different cell types and their dimensions in wood material (Koehler, 1924; Jane, 1970). In a piece of wood, for example, higher density wood has thicker cell walls.

\footnotetext{
${ }^{1}$ Forest Products Technology Research and Development Center, Bogor
} 
Wood density is the most commonly quoted wood property, which correlates to general characteristics as well as physical and mechanical properties (Dadswell, 1972). It is believed that denser wood is stronger, more stable and more durable. As a result, denser timber can be developed into various utilization, such as construction, furniture, cabinet as well as carving and sculpture.

Theoretically, wood material can be densified by various combinations of either chemical and thermal or compressive and thermal treatments. Such treatment would result in anatomical changes in the wood structure. This paper describes results of experiment investigating anatomical changes of kekabu wood due to mechanical densification.

\section{MATERIALS AND METHOD}

Kekabu trees were taken from Ciapus, a highland and the south of Bogor, West Java. Logs were sawn into square shaped specimens measuring $4 \mathrm{~cm} \times 4 \mathrm{~cm}$ with length of $50 \mathrm{~cm}$. The untreated and treated samples were arranged in pair. Before densification, the samples were steamed for 30 minutes in temperature of $126^{\circ} \mathrm{C}$. After steaming, the samples were compressed at $23.75 \mathrm{~kg} / \mathrm{cm}^{2}$ for 30 minutes.

Anatomical changes were analysed using conventional microscope and Scanning Electron Microscope (SEM). Parameters observed using conventional microscope were: vessel shape and size, vessel frequency per $25 \mathrm{~mm}^{2}$ and ray frequency per $\mathrm{mm}$. Meanwhile, fiber size and shape were analysed using SEM.

Density of compressed and control kekabu wood was determined in oven dry condition. Volume and weight of control and compressed samples were measured after drying in an oven at temperature of $103^{\circ} \mathrm{C}$.

\section{RESULTS AND DISCUSSION}

Comparison of cross sectional appearances between the compressed kekabu wood and the control can be seen in Figure 1. It is clear that the shape of vessels become oval to ellipse after compression. Such changes might be due to the heat applied during steaming that may soften the wood components, enabling the pressure to push round vessel becoming oval or elliptic. In this condition, the void volume in wood vessel is reduced, meaning the air in the void volume that does not support wood physically, is replaced with wood components that may give structural improvement. 


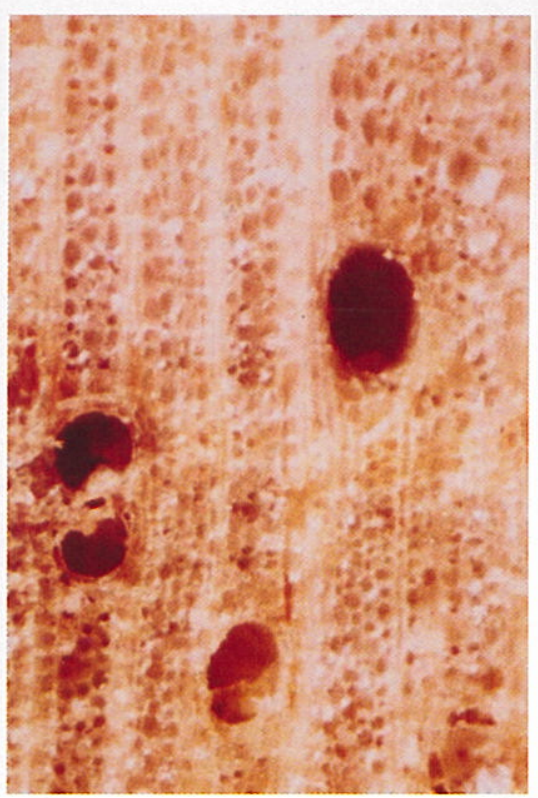

a

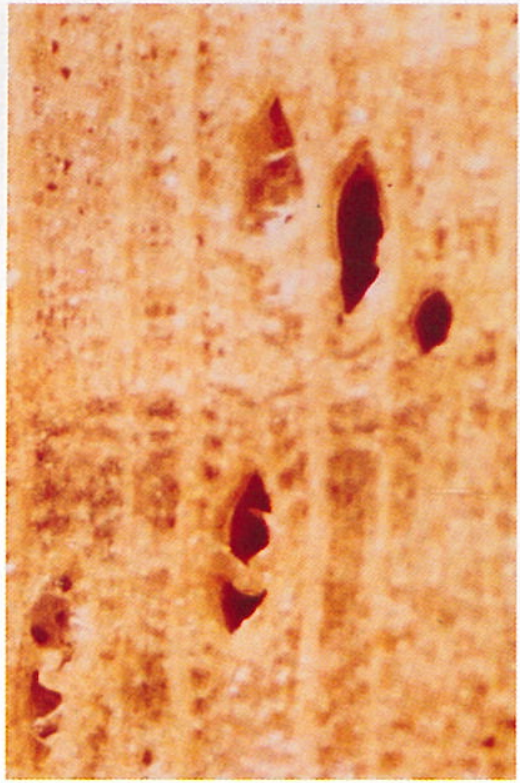

b

$200 \mu \mathrm{m}$

Figure 1. Round-shaped vessels in untreated kekabu wood (a) and oval to ellipse in compressed wood (b)

The treatment did not only change the vessel shape, but also did affect some changes in vessel's tangential diameter and its frequency per $25 \mathrm{~mm}^{2}$. The tangential diameter became smaller and its frequency tends to rise (Table 1.). The vessel diameter of untreated kekabu wood was about $172.44 \pm 7.4$ micron, while the compressed kekabu wood had a reduced vessel diameter of about $62 \%$. 
Table 1. Comparison of vessel tangential diameter, vessel frequency per $25 \mathrm{~mm}^{2}$ and ray frequency per mm compressed and unpressed kekabu wood

\begin{tabular}{|c|c|c|c|c|c|c|c|c|c|}
\hline \multirow[t]{2}{*}{$\begin{array}{c}\text { Sample } \\
\text { code }\end{array}$} & \multicolumn{3}{|c|}{$\begin{array}{l}\text { Tangential diameter of } \\
\text { vessel (micron) }\end{array}$} & \multicolumn{3}{|c|}{$\begin{array}{l}\text { Vessel frequency } \\
\text { per } 25 \mathrm{~mm}^{2}\end{array}$} & \multicolumn{3}{|c|}{$\begin{array}{l}\text { Ray frequency } \\
\text { Per mm }\end{array}$} \\
\hline & Untreated & Treated & \begin{tabular}{|c|}
$\begin{array}{c}\text { Change } \\
(\%)\end{array}$ \\
\end{tabular} & Untreated & Treated & $\begin{array}{c}\text { Change } \\
(\%)\end{array}$ & Untreated & Treated & $\begin{array}{c}\text { Change } \\
(\%)\end{array}$ \\
\hline $\mathrm{A}_{1} \mathrm{~B}_{1}$ & 160.00 & 66.67 & 58 & 27 & 35 & 30 & 6 & 12 & 100 \\
\hline $\mathrm{A}_{1} \mathrm{~B}_{2}$ & 186.67 & 53.33 & 71 & 26 & 34 & 31 & 5 & 10 & 100 \\
\hline $\mathrm{A}_{1} \mathrm{~B}_{3}$ & 200.00 & 80.00 & 60 & 25 & 36 & 44 & 7 & 12 & 71 \\
\hline $\mathrm{A}_{1} \mathrm{~B}_{4}$ & 146.67 & 53.33 & 63 & 24 & 34 & 42 & 6 & 12 & 100 \\
\hline $\mathrm{A}_{1} \mathrm{~B}_{5}$ & 173.33 & 93.33 & 46 & 30 & 36 & 20 & 5 & 12 & 140 \\
\hline $\mathrm{A}_{1} \mathrm{~B}_{6}$ & 160.00 & 53.33 & 66 & 31 & 35 & 13 & 4 & 8 & 100 \\
\hline $\mathrm{A}_{1} \mathrm{~B}_{7}$ & 186.67 & 66.67 & 64 & 28 & 34 & 21 & 6 & 10 & 67 \\
\hline $\mathrm{A}_{1} \mathrm{~B}_{8}$ & 133.33 & 80.00 & 40 & 27 & 33 & 22 & 8 & 12 & 50 \\
\hline $\mathrm{A}_{1} \mathrm{~B}_{9}$ & 146.67 & 53.33 & 63 & 26 & 32 & 23 & 6 & 11 & 83 \\
\hline $\mathrm{A}_{1} \mathrm{~B}_{10}$ & 186.67 & 66.67 & 64 & 25 & 33 & 32 & 5 & 10 & 100 \\
\hline $\mathrm{B}_{1} \mathrm{~B}_{1}$ & 186.67 & 53.33 & 71 & 24 & 30 & 25 & 7 & 12 & 71 \\
\hline $\mathrm{B}_{1} \mathrm{~B}_{2}$ & 173.33 & 40.00 & 77 & 25 & 36 & 44 & 6 & 11 & 83 \\
\hline $\mathrm{B}_{1} \mathrm{~B}_{3}$ & 186.67 & 80.00 & 57 & 27 & 35 & 30 & 4 & 10 & 150 \\
\hline $\mathrm{B}_{1} \mathrm{~B}_{4}$ & 160.00 & 66.67 & 58 & 27 & 35 & 30 & 6 & 8 & 33 \\
\hline $\mathrm{B}_{1} \mathrm{~B}_{5}{ }^{-}$ & 146.67 & 53.33 & 64 & 26 & 32 & 23 & 8 & 12 & 50 \\
\hline $\mathrm{B}_{1} \mathrm{~B}_{6}$ & 173.33 & 80.00 & 54 & 28 & 34 & 21 & 6 & 10 & 67 \\
\hline $\mathrm{B}_{1} \mathrm{~B}_{7}$ & 186.67 & 53.33 & 71 & 29 & 35 & 21 & 5 & 12 & 140 \\
\hline $\mathrm{B}_{1} \mathrm{~B}_{8}$ & 160.00 & 53.33 & 67 & 30 & 36 & 20 & 7 & 14 & 100 \\
\hline $\mathrm{BiB}_{9}$ & 146.67 & 53.33 & 64 & 27 & 33 & 22 & 6 & 13 & 117 \\
\hline $\mathrm{B}_{1} \mathrm{~B}_{10}$ & 133.33 & 66.67 & 50 & 28 & 32 & 14 & 4 & 12 & 200 \\
\hline $\mathrm{B}_{1} \mathrm{C}_{1}$ & 160.00 & 80.00 & 50 & 27 & 34 & 26 & 6 & 10 & 67 \\
\hline $\mathrm{B}_{1} \mathrm{C}_{2}$ & 186.67 & 66.67 & 64 & 29 & 33 & 14 & 8 & 15 & 87 \\
\hline $\mathrm{B}_{1} \mathrm{C}_{3}$ & 200.00 & 53.33 & 73 & 30 & 32 & 7 & 6 & 10 & 67 \\
\hline $\mathrm{B}_{1} \mathrm{C}_{4}$ & 213.33 & 80.00 & 62 & 31 & 34 & 10 & 5 & 10 & 100 \\
\hline $\mathrm{B}_{1} \mathrm{C}_{5}$ & 173.33 & 93.33 & 46 & 32 & 33 & 13 & 7 & 12 & 71 \\
\hline $\mathrm{B}_{1} \mathrm{C}_{6}$ & 186.67 & 53.33 & 71 & 28 & 31 & 11 & 6 & 11 & 83 \\
\hline $\mathrm{B}_{1} \mathrm{C}_{7}$ & 173.33 & 53.33 & 69 & 27 & 32 & 18 & 4 & 8 & 100 \\
\hline $\mathrm{B}_{1} \mathrm{C}_{8}$ & 200.00 & 66.67 & 67 & 26 & 34 & 31 & 6 & 12 & 100 \\
\hline $\mathrm{B}_{1} \mathrm{C}_{9}$ & 160.00 & 80.00 & 50 & 25 & 33 & 32 & 8 & 12 & 50 \\
\hline $\mathrm{B}_{1} \mathrm{C}_{10}$ & 186.67 & 66.70 & 64 & 25 & 32 & 28 & 6 & 13 & 117 \\
\hline Average & 172.44 & 65.33 & 62 & 27.33 & 33.70 & 11.2 & 5.97 & 11.20 & 92.17 \\
\hline
\end{tabular}

Vessel's frequency of the compressed samples was denser than that of the untreated samples. Average frequency of the untreated samples was about 27 vessels per $25 \mathrm{~mm}^{2}$, then increased to 34 vessels per $25 \mathrm{~mm}^{2}$ after compression. The change of $23 \%$ was particularly caused by the great reduction in vessel diameter as mentioned earlier.

Ray frequency of the compressed samples was significantly higher than that of the control (Table 1). The ray frequency of compressed samples was almost twice that of the untreated samples. The compressed wood had in average more than 11 ray per $\mathrm{mm}$, while 
the untreated samples had only 6 rays per $\mathrm{mm}$. Figure 2 clearly showed the difference between the control and treated samples. Such notable changes were particularly due to the pressure direction imposed during treatment where most of the samples were compressed tangentially, leaving more changes in radial feature.

Paired T-tests in Table 2. indicated that all parameters as measured: vessel diameter, vessel frequency and ray frequency were significantly different at the level of confidence of $95 \%$.

Table 2. Results of T-test on paired samples

\begin{tabular}{|l|l|l|l|c|}
\hline & & df & T & T table \\
\hline Pair 1 (vessel diameter) & Pressed vs Control & 29 & $25.120 * *$ & 2.04 \\
\hline Pair 2 (vessel frequency) & Pressed vs Control & 29 & $15.706 * *$ & 2.04 \\
\hline Pair 3 (ray frequency) & Pressed vs Control & 29 & $21.130 * *$ & 2.04 \\
\hline
\end{tabular}

Remarks: ** Significantly different at the level of confidence $95 \%$

Results of further analysis using SEM were presented in Figures 2, 3 and 4. It is clear from those figures that there had been notable changes in general structure of the treated samples. Shape of the fiber cells in general became elliptic with several deformations between them. Such deformation may result in some reduction in mechanical strength. Densification also exists in ray tissues which became thinner and more closely arranged in the treated samples (Figure 3).

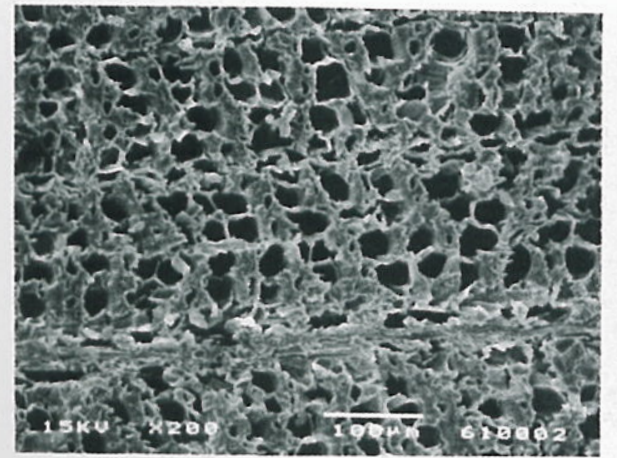

a

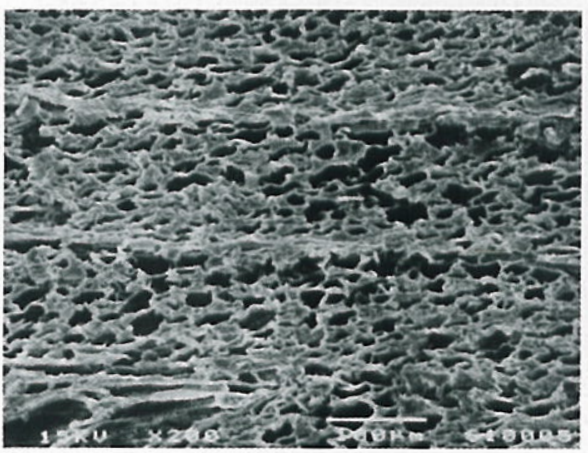

b

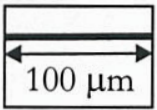

Figure 2. Transversal surface of untreated kekabu (a), treated kekabu wood (b) analysed by Scanning Electron Microscopy (SEM) 


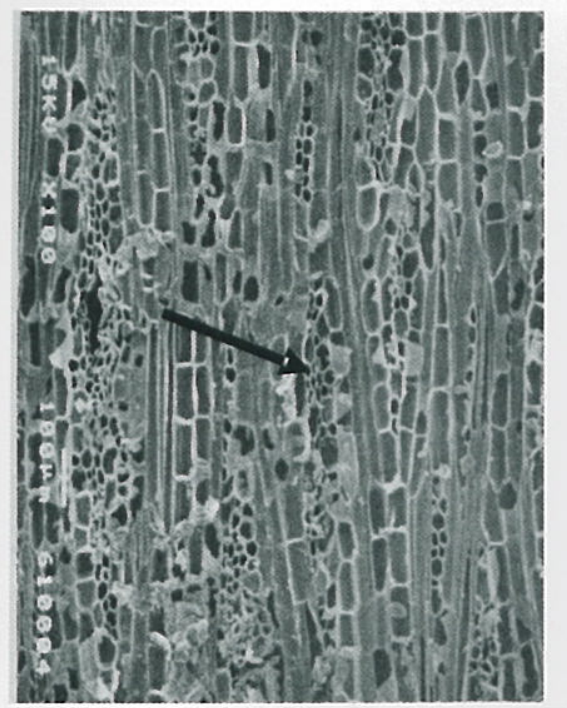

a

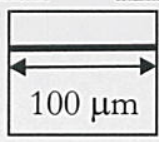

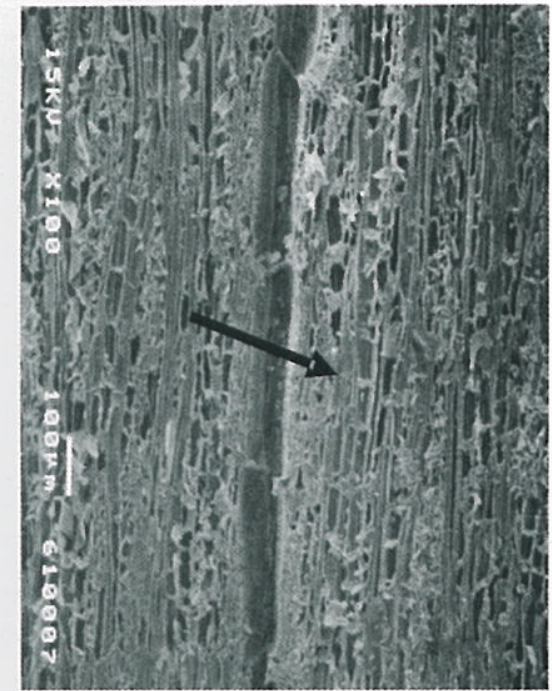

b

Figure 3. Tangential surface of untreated kekabu (a) shows normal ray, treated kekabu wood (b) shows thinner ray

Some parts of the treated samples, approximately $20 \%$, indicated a fully densified fiber tissues (Figure 4.). Most of the fully densified regions were found in the outer side of specimen and also near to the growth rings. This might be due to the uneven effect of the pressure in the wood structure, where the wood cells in the outer side received more forces during compression, leaving this part fully densified. Higher densification near the growth rings was probably due to thinner cell wall in growth ring area, making it more responsive to pressure and therefore experienced greater changes. 


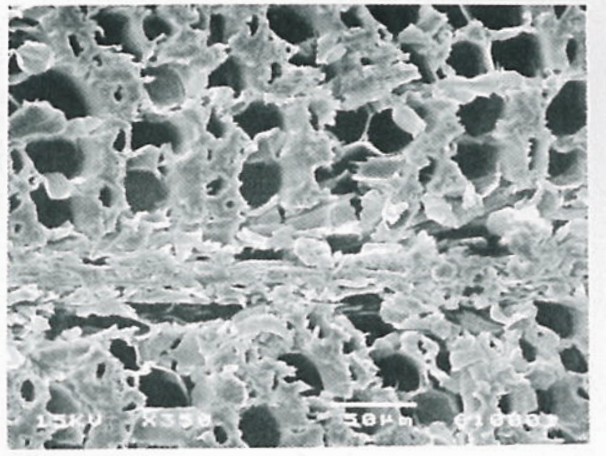

a

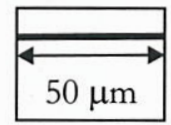

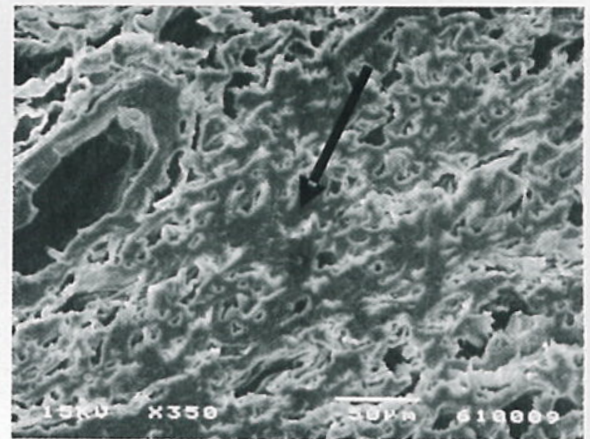

b

Figure 4. Untreated kekabu (a), treated kekabu wood (b) analysed by Scanning Electron Microscopy (SEM). Arrow indicates fully densified fiber tissue

The anatomical changes mentioned above could affect some physical changes as those clearly shown in density improvement in the treated samples (Table 3). The average density of untreated kekabu wood is about $0.33 \mathrm{~g} / \mathrm{cm}^{3}$, while the compressed wood is about 0.52 $\mathrm{g} / \mathrm{cm}^{3}$. Density improvement of compressed kekabu wood is approximately $53.6 \%$. However, Pearson correlation tests indicated a weak relationship between density improvement and other single parameter as observed in this study. 
Table 3. Density improvement in compressed kekabu wood

\begin{tabular}{|c|c|c|c|}
\hline \multirow[t]{2}{*}{ Sample code } & \multicolumn{2}{|c|}{$\begin{array}{l}\text { Density } \\
\left(\mathrm{g} / \mathrm{cm}^{3}\right)\end{array}$} & \multirow[t]{2}{*}{$\begin{array}{l}\text { Density Improvement } \\
(\%)\end{array}$} \\
\hline & Untreated & Treated & \\
\hline$A_{1} B_{1}$ & 0.41 & 0.54 & 33.9 \\
\hline $\mathrm{A}_{1} \mathrm{~B}_{2}$ & 0.31 & 0.46 & 47.9 \\
\hline $\mathrm{A}_{1} \mathrm{~B}_{3}$ & 0.35 & 0.59 & 69.1 \\
\hline $\mathrm{A}_{1} \mathrm{~B}_{4}$ & 0.34 & 0.53 & 55.7 \\
\hline $\mathrm{A}_{1} \mathrm{~B}_{5}$ & 0.34 & 0.51 & 51.3 \\
\hline $\mathrm{A}_{1} \mathrm{~B}_{6}$ & 0.36 & 0.51 & 42.7 \\
\hline$A_{1} B_{7}$ & 0.34 & 0.44 & 31.8 \\
\hline $\mathrm{A}_{1} \mathrm{~B}_{3}$ & 0.32 & 0.48 & 48.6 \\
\hline $\mathrm{A}_{1} \mathrm{~B}_{9}$ & 0.34 & 0.52 & 52.5 \\
\hline$A_{1} B_{10}$ & 0.28 & 0.50 & 75.6 \\
\hline $\mathrm{B}_{1} \mathrm{~B}_{1}$ & 0.41 & 0.56 & 36.1 \\
\hline $\mathrm{B}_{1} \mathrm{~B}_{2}$ & 0.30 & 0.54 & 78.7 \\
\hline $\mathrm{B}_{1} \mathrm{~B}_{3}$ & 0.34 & 0.58 & 69.8 \\
\hline $\mathrm{B}_{1} \mathrm{~B}_{4}$ & 0.34 & 0.44 & 29.6 \\
\hline $\mathrm{B}_{1} \mathrm{~B}_{5}$ & 0.34 & 0.52 & 53.0 \\
\hline $\mathrm{B}_{1} \mathrm{~B}_{6}$ & 0.36 & 0.51 & 44.1 \\
\hline $\mathrm{B}_{1} \mathrm{~B}_{7}$ & 0.34 & 0.44 & 31.0 \\
\hline $\mathrm{B}_{1} \mathrm{~B}_{3}$ & 0.36 & 0.58 & 62.7 \\
\hline $\mathrm{B}_{1} \mathrm{~B}_{9}$ & 0.34 & 0.51 & 51.6 \\
\hline $\mathrm{B}_{1} \mathrm{~B}_{10}$ & 0.29 & 0.50 & 74.5 \\
\hline $\mathrm{B}_{1} \mathrm{C}_{1}$ & 0.42 & 0.57 & 34.1 \\
\hline $\mathrm{B}_{1} \mathrm{C}_{2}$ & 0.31 & 0.54 & 74.2 \\
\hline $\mathrm{B}_{1} \mathrm{C}_{3}$ & 0.35 & 0.60 & 72.1 \\
\hline $\mathrm{B}_{1} \mathrm{C}_{4}$ & 0.26 & 0.45 & 73.7 \\
\hline $\mathrm{B}_{1} \mathrm{C}_{5}$ & 0.35 & 0.53 & 52.9 \\
\hline $\mathrm{B}_{1} \mathrm{C}_{6}$ & 0.37 & 0.52 & 40.4 \\
\hline $\mathrm{B}_{1} \mathrm{C}_{7}$ & 0.34 & 0.45 & 31.5 \\
\hline $\mathrm{B}_{1} \mathrm{C}_{3}$ & 0.27 & 0.43 & 57.1 \\
\hline $\mathrm{B}_{1} \mathrm{C}_{9}$ & 0.35 & 0.61 & 75.4 \\
\hline $\mathrm{B}_{1} \mathrm{C}_{10}$ & 0.32 & 0.50 & 57.3 \\
\hline Average & 0.33 & 0.52 & 53.6 \\
\hline
\end{tabular}

The effect of compression on anatomical changes was dependent upon grain orientation of wood specimen. In fully quarter sawn, the compression imposed perpendicularly to grain orientation, resulted in anatomical changes as shown in Figure 5a. In semi-quarter sawn, samples moved obliquely to the grain, leaving a different anatomical changes as shown in Figure $5 b$. 


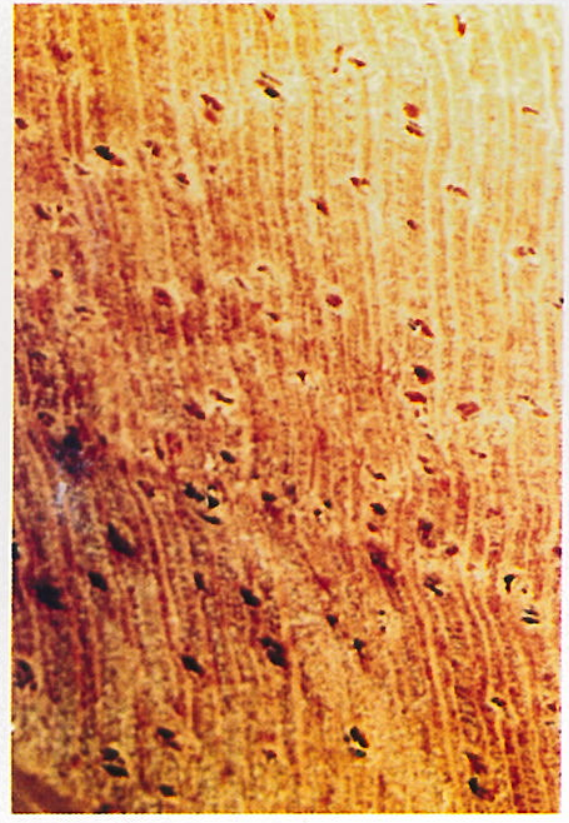

a

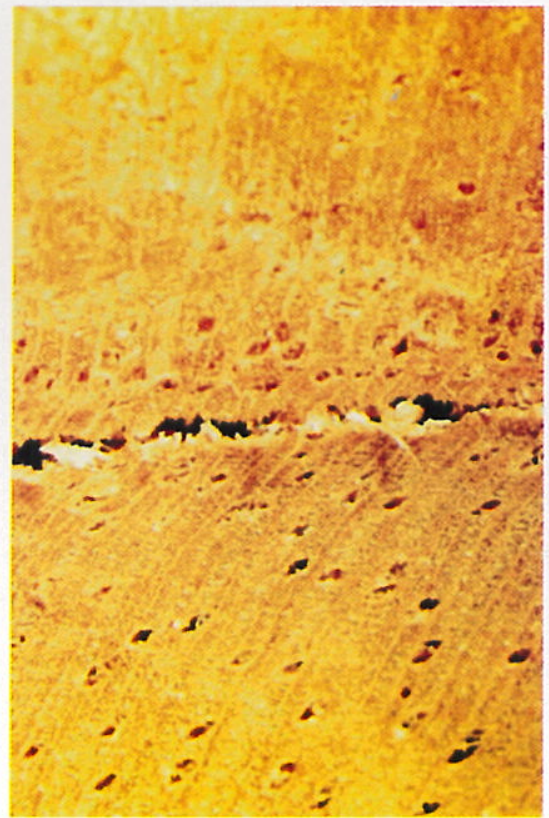

b

$$
1 \mathrm{~mm}
$$

Figure 5. Kekabu wood after compression with sloping forces (a) fully quartersawn (b) semi quartersawn

After compression, shape of most vessels became oval or elliptical with certain pattern following the imposed forces. The oblique forces pressed the ray tissue irregularly, generating a wavy ray orientation. The sloping forces could even create checks or cracks on growth rings, where a band of axial parenchyma with thin cell wall was encountered; a common characteristics of transition tissues.

\section{CONCLUSION}

1. Mechanical densification generated anatomical changes of kekabu wood both structurally and dimensionally.

2. The densification could result in some deformations on growth rings and non structural tissues.

3. The effect of compression on anatomical changes depend on grain orientation of the wood samples. 


\section{REFERENCES}

Ba and Nghia Tin. 1998. General part of Bombax. In Sosef, M.S.M., L.T. Hong and S. Prawirohatmodjo (Eds.) Plant Resources of South East Asia, Timber trees: Lesserknown timbers, Vol. 5(3). Backhuys Publication, Leiden.

Dadswell, H.E. 1972. The anatomy of Eucalyptus woods. Technological paper No. 66. Commonwealth Scientific and Industrial Research Organization (CSIRO), Division of Forest Products, Melbourne.

Jane, F.W. 1970. The Structure of Wood. Rev.ed. Adam and Charles, London.

Koehler, A. 1924. The Properties and Uses of Wood. McGraw Hill Book Company, New York.

Kollman, F.P., E.W. Kuenzi and A.J. Stamm. 1975. Principles of Wood Science and Technology. Vol. II. Wood based materials. Springer-Verlag New York, Heidelberg, Berlin.

Oey D.S. 1990. Berat jenis kayu Indonesia dan pengertian beratnya kayu untuk keperluan praktek. Pengumuman No. 11. Lembaga Penelitian Hasil Hutan dan Sosial Ekonomi Kehutanan, Bogor. 